\title{
Die sentrale openbaring in die Ou Testament en die Christelike grondslag van die Potchefstroomse Universiteit
}

F.N. Lion-Cachet

Departement Ou en Nuwe Testament

Potchefstroomse Universiteit vir $\mathrm{CHO}$

POTCHEFSTROOM

\begin{abstract}
The central revelation in the Old Testament and the Christian foundation of the Potchefstoom University

The PU for CHE acknowledges the revelation of God in creation and his Word as its foundation. The issue concerning the focus of the revelation in Scripture is answered in different ways. Looking at the Old Testament from a revelatory-cognitive approach, the LORD's own disclosure as "I am who I am" (Exodus 3:14) may be a meaningful response. The concept "I am who I am" has a incomprehensible as well as a comprehensible meaning which reveals our knowledge of the LORD in a great diversity (He is God, the Creator, the Saviour, the Holy One, etc.). In addition, Christ proclaimed Himself in the New Testament as "I am ...". This central concept opens up the opportunity for a Christian university to do scientific work with the full reality of creation as its object.
\end{abstract}

\section{Die inleiding}

In sy missie word gestel dat die Potchefstroomse Universiteit op 'n Christelike grondslag staan en diensgerig vir die tyd, die land en sy mense wil wees. Bogenoemde missie kan heelwat vrae ontlok soos onder andere: wat word met die openbaring in die skepping bedoel, of, wat is die openbaring in die Skrif, en hou dit verband met ' $n$ sentrale openbaring (wat self ' $n$ teologiese vraagstuk is) of, hoe het die (sentrale) openbaring in die Skrif met Christus te doen?

'n Bespreking van bogenoemde probleemstellings kan op verskillende vlakke geskied (vanuit Ou- en Nuwe-Testamentiese, dogmatiese en filosofiese gesigspunte). In hierdie artikel sal met die kennis wat van die openbaring van God verkry is en vanuit 'n Ou-Testamentiese perspektief na die begrip sentrale openbaring gekyk word. Ook sal getoets word of daar 'n verband is tussen dié 
Die sentrale openbaring in die O.T. en die Christelike grondslag van die PU

sentrale openbaring en die Christelike grondslag, onderrig en wetenskapsbeoefening wat as die wesenseie van die Universiteit gestel word. As hipotese word gestel dat die sentrale openbaring in die Ou Testament romdom die kennis van Jahweh wentel - Jahweh wat die God van sy volk is. Hierdie kennis van God is volgens die Nuwe Testament alleen in Christus moontlik.

\section{Kriteria vir die bepaling van die sentrale openbaring.}

Eerstens moet daar duidelikheid wees oor die aard van die begrip sentrale openbaring. Is dit 'n verhoudingsbegrip (tussen God en die mens, of tussen die mens en God of tussen die mense onderling - soos gesien vanuit 'n antropologiese, sosiologiese of ander gesigspunte) of is dit primêr 'n Godsbegrip (eksistensialisties), of is dit al twee? Tweedens moet 'n vraag na die metodologie beantwoord word. Waar moet die ondersoek begin word? Is dit die mees voorkomende begrip? Moet die antwoord in die dade of in die woorde van God gesoek word? Gaan dit om die saamgevatte boodskap/gedagte of direkte teksgetuienis? In hoeverre moet die Nuwe-Testamentiese teologie in ag geneem word?

Die vraag of die Skrifgetuienis primêr oor die wese van God gaan en/of oor die verhouding van God tot die mens, moet nie te haastig afgemaak en alleen tot 'n verhoudingsidee beperk word nie (soos Smend, 1970:48), maar verdere navorsing en besinning is nodig.

Metodologies moet 'n teologiese ondersoek direk by die Ou-Testamentiese teksgetuienis begin. Verkieslik word gesoek na die eenvoudigste en helderste teks waaruit die begrip deduktief verkry kan word. In die Christelike teologie word die onlosmaaklike verband tussen die $\mathrm{Ou}$ en die Nuwe Testament erken en geïmplementeer en bly die ganse Skrif tot vandag aktueel (vgl. Childs, 1989:7-9; Kaiser, 1991:24; Clements, 1978:1, 21, 19). In die aanvaarding dat die ganse Bybel God se woord is en die eenheid van die Bybel in God self rus, kan dit verwag word dat die openbaringsbegrip by al die Bybelskrywers van die Pentateug tot Openbaring bekend moes gewees het (vgl. Kaiser, 1991:20-23, 32). Dat die eenheid van die Skrif in God self rus, impliseer wel dat 'n sentrale openbaringsgedagte ' $n$ moontlikheid is en spreek teen die mening dat die Skrif uit verskillende teologieë van mense bestaan (soos by Von Rad, 1965:414). Die Ou Testament kan wel meer as een openbaringslyn bevat, maar dit beteken nie dat die begrip wat die meeste voorkom (die kwantiteit), die hooflyn moet wees nie. Dit gaan om die waarde (kwaliteit) van wat geopenbaar is en of hierdie openbaringskennis aan die Bybelskrywers bekend was.

In die keuse van tekste moet teologiese voorkeure sover moontlik vermy word. Verder moet die volgende sekerlik in ag geneem word: 
F.N. Lion-Cachet

* Die sentrale begrip sal waarskynlik 'n omvattende karakter vertoon Hier moet teen 'n sisteemdwang gewaak word (vgl. Hasel, 1972:123) want 'n bepaalde sisteemstruktuur kan daartoe lei dat "nie-sentrale" begrippe kunsmatig tot onderdele van 'n gekose sentrale begrip gereduseer word.

* Die sentrale begrip hoef nie alles te verklaar nie

Die teoloog het nie bloot met 'n historiese verskynsel te doen nie, maar soek kunde van God wat wel in die geskiedenis opgetree het, maar nie volledig in menslike begrippe uitgedruk kan word nie. Die kennis aangaande Hom is helder én onduidelik, dit open ons insig én dit eis geloof in die onsienlike, dit hoort tot die verlede én tot die toekoms (eskatologie). Die openbaring is nie net vertikaal nie maar ook horisontaal (vgl. Childs, 1989:22).

* Die sentrale begrip mag nie religieus, literêr, filosofies of sosiologies bepaal word nie

Die begrip hang nie van menslike kundigheid af nie. Daarom moet gedagtes soos dat elke religie 'n grondidee moet hê (soos by Smend, 1970:7), of dat elke teologie of literêre produk of filosofie 'n basiese struktuur moet hê, of dat elke progressiewe sosiale samelewing deur 'n sentrale beleidsmotief gedrywe is, verwerp word (vgl. ook Childs, 1989:7). As openbaring van God het die sentrale openbaringsbegrip historiese sowel as normatiewe waarde (vgl. Childs, 1989:12, 13).

* Die resultaat van die navorsing moet natuurlik deeglik geverifieer en deur die uitsprake van ander gekontroleer word

Die bepaling van 'n sentrale openbaring bly per slot van sake menslike teologiese arbeid. Enige navorsing moet dus van eeuelange navorsing en kerklike belydenisskrifte kennis neem.

\section{Antwoorde in die verlede}

Die Ou-Testamentiese teologie het hom reeds van die begin van sy wetenskaplike arbeid met die formulering van 'n Grundidee, Mitte, Zentralhegriff, central concept, centre, ensovoort besig gehou. Vir 'n oorsig van die navorsingsgeskiedenis en verskillende voorstelle vir hierdie sogenaamde sentrale begrip vanaf De Wette (1813), vergelyk Smend (1970:725), Hasel (1972:117-140), Hayes en Prussner (1985:257-259). Begrippe soos die volgende is al genoem: God se verbond (wat deur Eichrodt, 1961, as 'n eerste omvattende teologiese navorsing aangebied is), God se verkiesing, sy belofte, sy koninkryk, die gemeenskap van God, die heiligheid van God, die heerskappy én gemeenskap van God. Uitsprake soos die volgende is ook al as 'n grondidee of sentrale begrip getipeer: "Ek is Jahweh jou God", of Jahweh die God van Israel en Israel die volk van Jahweh, God se verbond en koninkryk, Jahweh die God van Israel, Ek is Jahweh en "EK IS WAT EK IS" (Eksodus

Koers 60(4) 1995:563-577 
Die sentrale openbaring in die O.T. en die Christelike grondslag van die $P U$

3:14). Ook is God self of die aktiwiteit van God in die geskiedenis en selfs die boek Deuteronomium al genoem. Daar is gepoog om met Nuwe-Testamentiese lig tot 'n aanvaarbare gedagte te kom - soos die belydenis van Paulus in Handelinge 13:16 e.v. (vgl. Wright, 1952:349-350). Baie ondersoekers en navorsers ontken dat daar enige fokus is (o.a. Von Rad, 1965:362 alhoewel Hasel [1972:123-124] meen dat Von Rad ondanks sy ontkenning tog met ' $n$ middelpunt werk). Hasel is baie krities ten opsigte van die gedagte van bogenoemde sentrale begrippe vir die Ou Testament, maar hy sê uiteindelik tog ook "... God is the dinamic, unifying center of the Old Testament" (1972:140, 179).

Uit bogenoemde oorsig blyk dat navorsers geen eenstemmigheid bereik het nie. Daarby het al die begrippe al skerp kritiek ontlok - onder andere die beperktheid van die begrippe, die geïsoleerdheid waarin sommige begrippe voorkom. Ook is die gebrek aan direkte teksgetuienis vanaf Genesis tot Openbaring en sisteemdwang as swakhede aangetoon (vgl. Smend, 1970:7-25; Hasel, 1972:117-140; Stek, 1994:12-41; Schmidt, 1983:144-148).

Aan die ander kant moet opgemerk word dat elke formulering wel teksgronde het. In al die omskrywings van die sentrale openbaringslyn is dit opmerklik dat dit om God of Jahweh gaan en dat een van sy deugde (bv. sy heiligheid) of sy verhouding tot Israel of sy volk (sy verbond, sy heerskappy, sy gemeenskap) genoem word. Die veelvuldige formulerings toon iets van die glansryke majesteit, die kleurrykheid of die veelvuldige wysheid van God (Ef. 3:10).

Die feit dat die sentrale openbaring verhoudingsrelasies beklemtoon, roep die mens of volksgemeenskap tot verantwoording. Die mense word dinamies betrek en hulle sal hulle nie goedsmoeds van die HERE (die drie-enige) God of Christus kan onttrek nie (Ef. 2:9-11).

\section{4. 'n Ou-Testamentiese ondersoek}

Niemand kan God ken as Hy Hom nie aan die mens bekend gemaak het nie. In besonder maak God Hom aan die mens bekend deur sy verskynings, sy woord deur die profete en deur die wonder in die voortgang van die natuur en geskiedenis (vgl. Bavinck, 1918:340; Helberg, 1980:1-2; Von Rad, 1965:358). Die verskynings en die eie woorde van God waarin Hy Homself met "Ek is ..." bekend stel (direk of deur die mond van die profete/apostels), kan 'n sleutel wees om die sentrale openbaringsboodskap te verstaan. Die teks van hierdie 
F.N. Lion-Cachet

"Ek is ... "-sinne, met die klem op die "Ek", loop soos 'n goue draad deur die hele Skrif. 1

God se optrede in die geskiedenis begin nie met 'n selfbekendstelling nie. Die eerste bekendstelling word aan Abraham gedoen (Gen. 15:1, 7; 17:1) maar dan doen Hy dit in 'n tipies Oud-Oosterse idioom (as God die Almagtige) en in 'n tyd waarin die Ou-Testamentiese openbaring moontlik nog nie skriftelik opgeteken is nie. Die mees epogmakende bekendstelling vind eers in die dae van Moses plaas. God maak Hom dan as Jahweh bekend (vgl. Eks. 3, 6:2 [3] en dit is in 'n tyd waarin die belangrikste dokument op kliptablette gegee word - vgl. Eks. 20:1-17; Deut. 5:6-21). Op grond van bogenoemde word die bekendstelling in die roepingsgeskiedenis van Moses (Eks. 3:1-4:17) as Argimedespunt geneem (Schmidt en Zimmerli het by die eerste gebod in die Dekaloog begin en veral by die bekendstelling "Ek is die HERE jou God"; vgl. Zimmerli, 1978:17, met kommentaar van Hasel, 1972:130-133).

- Die openbaring in die roepingsgeskiedenis van Moses (Eks. 3:1-4:17) Die afbakening van dié perikoop het sy oorsprong by die Masorete. Dit is deur verskillende Bybelvertalings en kommentare erken (vir 'n breër bespreking raadpleeg Childs, 1974:51-52). 'n Literêr-kritiese beoordeling reken dat die teks hoofsaaklik uit die vroegste J-bron met enkele E-gedeeltes saamgestel is (vgl. Childs, 1974:52; Noth, 1962:28). Die moontlikheid van ou tradisies kan nie ontken word nie, maar dit sluit die historiese realiteit nie noodwendig uit nie. In die lig van die gesagvolheid van die Pentateug is laasgenoemde moontlikheid verkieslik. Hier word nie op die hele vraagstuk in verband met die openbaringskarakter en die veelvormigheid of multidimensionaliteit van die Ou Testament ingegaan nie omdat dit buite die raamwerk van hierdie artikel val (vir bespreking van die vraagstuk vgl. Lion-Cachet, 1995:38-44).

$1 \quad$ Vgl. onder andere: Gen. 15:1, 7; 17:1; 26:24; 28:15; 31:13; 35:11; Eks. 3:6, 14; 6:1-2 [MT:2-3], 6-8 [7-9]; 8:22 [18]; 10:2; 12:12; 20:2; 29:46; 31:13; Lev. 11:44; 20:7; Num. 18:20; Deut. 5:6; 32:39; Ps. 50:7; 81:11; Jes. 41:10; 42:8; $43: 3,5,10,11,12,13,15,25 ; 44: 6,24 ; 45: 5,18,22 ; 48: 17 ; 52: 6$; Jer. 1:8, 19; 9:24 [23]; 24:7; 30:11; 32:27; 46:28; Eseg. 6:7, 10; 7:9; 12:15, 16; 33:29; 37:6; 39:7; Joël 3:17 [4:17]; Mal. 3:6; Matt. 11:29; 14:27; 22:32; 28:20; Mark. 6:50; 14:61-62; Luk. 22:70; 24:39; Joh. 4:26; 6:2, 41, 48, 51; 8:12, 8:18, 24, 28, $58 ; 9: 9 ; 10: 7,11 ; 11: 25 ; 14: 6 ; 15: 1,5 ; 18: 5,6,8$; Hand. 9:5; 18:10; Op. 1:11, $17 ; 2: 23 ; 21: 6 ; 22: 16$ ). 
Die sentrale openbaring in die O.T. en die Christelike grondslag van die $P U$

- 'n Kort oorsigtelike aanduiding van die gebeure en die dialoog tussen God en Moses kan soos volg daar uitsien:

In hierdie teksgedeeltes volg die optrede of woorde van die HERE of dié van Moses of andersom (aangedui deur \#). Moses se besware word numeries (1-5) aangedui.
Eksodus 3:1-2 - Situasie
Eksodus 3:3-5 - Moses: nader \# Jahweh: heilige grond
Eksodus 3:6 - Jahweh: God van vaders \# Moses: vrees
Eksodus 3:7-10 - Jahweh: Ek het gesien ... lei hulle uit
Eksodus 3:11-12 - Moses: (1) Ek? \# Jahweh: Ek is met jou.
Eksodus 3:13-15 - Moses: (2) Wie is U? \# Jahweh: EK IS.
Eksodus 3:16-22 - Jahweh: Ek gee ag ... Ek wil laat optrek.
Eksodus 4:1-9 - Moses: (3) As hulle my nie glo nie \# Jahweh: Drie tekens (slang, hand, water).
Eksodus 4:10-12 - Moses: (4) Ek is swaar van mond \# Jahweh: Ek maak die mond en sal jou leer. $\begin{aligned} \text { Eksodus 4:13-17 - } & \text { Moses: (5) Here stuur wie u wil \# Jahweh: } \\ & \text { Aäron sal praat ... begin nou! }\end{aligned}$

Uit hierdie samevatting van die hooflyne in hierdie hoofstukke blyk dit dat die roepingsgeskiedenis eerstens die situasie van Moses by die brandende doringbos in Midian beskrywe (3:1-2). Die verdere geskiedenis verloop in 'n kommunikasieproses tussen Jahweh en Moses. Moses reageer op die vreemde verskynsel van die brandende doringbos, maar Jahweh waarsku dat die grond waarop hy staan heilige grond is (3:5). Jahweh kondig homself aan as die God van die voorvaders, Abraham, Isak en Jakob (die God wat aan sy verbond met hulle gedink het; vgl. 2:24) en Moses reageer deur sy aangesig uit vrees te verberg (3:6). Dan volg die roeping: Jahweh motiveer eers sy roepingsopdrag deur te kenne te gee dat Hy gesien, gehoor en geweet het van die lyding van sy volk en dat Hy van plan is om hulle uit die hand van die Egiptenaars te verlos. $\mathrm{Om}$ dit te beklemtoon herhaal $\mathrm{Hy}$ weer dat $\mathrm{Hy}$ gesien het. Daarna stuur $\mathrm{Hy}$ Moses om sy volk uit te lei (3:7-10).

Hierop het Moses begin om besware na vore te bring. Die besware is klassieke voorbeelde van mense wat met hulle roeping worstel. In Jahweh se antwoorde stel Hy Homself op 'n duidelike (die duidelikste in die Ou Testament) aan Moses bekend. Moses se eerste beswaar het betrekking op sy eie nietigheid: "Wie is ek?". Hy ag homself nie vir die taak waardig nie. Jahweh verseker hom dat Hy by hom sal wees ("God met ons") en gee hom 'n teken (3:11-12). Dan vra Moses op 'n taktvolle manier "wat is U Naam?" of "wie is U?" of "hoe is U?' warop Jahweh hom op die helderste én die onverstaanbaarste wyse 
F.N. Lion-Cachet

antwoord "EK IS WAT EK IS" (3:13-15). Hierop volg Jahweh se tweede roepings- of uitsturingsbevel waarin Moses se opdrag duideliker uitgespel word. Hy word ook verseker dat die volk hom sal glo maar die koning nie (3:16-22).

Moses bly teensinnig en twyfel of die volk hom sal glo. Hy spreek Jahweh selfs as Here (Meneer) aan. Hierop het Jahweh aan hom drie wondertekens gegee. Die tekens het betrekking op die beheersing van die dier, die mens en die natuur ((4:1-9). Moses se vierde beswaar raak sy onvermoë om te spreek. Jahweh kom met 'n wedervraag: "Wie het vir die mens 'n mond gemaak/gegee (מ) ... ? Is dit nie Ek, Jahweh nie?" (4:10-12). Moses se laaste beswaar word as 'n sugkreet uitgespreek. Hy spreek Jahweh weer nie as Jahweh aan nie maar as Here en wil die keuse van 'n leier aan Jahweh oorlaat asof Jahweh nie alreeds gekies het nie. Toe het Jahweh kwaad geword en Aäron as hulp aangewys en te kenne gegee dat Moses sy staf moet vat en met sy opdrag moet begin (4:13-17). (Vir' $n$ verklarende oorsig vgl. Fensham, 1970:23-29; Childs, 1974:45-89; Noth, 1962:38-47.)

Die sentrale selfbekendstelling in hierdie perikoop is die woorde "EK IS WAT EK IS" (3:13-15) en "Ek is die God van jou vader ... ", of, "die HERE, die God van julle vaders" $(3: 6,16)$. Jahweh dui Honself ook as die Verlosser aan (3:710, 16-22), as die God van gemeenskap (3:12), as Jahweh wat heilig is (3:3-5) en tot stand bring (skep) (4:11). Volledigheidshalwe word ook kennis geneem van ander Ou-Testamentiese bekendstellings wat die enigheid of die alleenbestaan van die HERE God en sy mag tot wetgewing (o.a. in die Dekaloog), en sy koningskap (Jes. 43:15 en 44:6) aantoon.

\subsection{Die Naam "EK IS WAT EK IS" en Jahweh}

In die Ou Ooste is 'n hoë waarde geheg aan die naam van 'n persoon wat in baie gevalle die uitdrukking van die wese van die persoon was en wat deur naamskending benadeel kon word (vgl. Zimmerli, 1978:18). Jakob wou weet wat die naam was van die man wat met hom geworstel het, maar hy het eintlik geen antwoord gekry nie (Gen. 32:29 [J]). In Rigters 13:18 word Manoag geantwoord dat die engel van die HERE se naam "wonderbaar" is.

Die eerste en mees omvattende selfopenbaring van die naam van God kom op aandrang van Moses voor (3:14). God het vir Moses gesê: "EK IS WAT EK IS" (אהיה אשר אהיה). Daarmee vestig Hy Moses se dringende aandag op Jahweh en sy selfverheerliking (Helberg, 1988:283; Günther, 1971:219; Stauffer, 1964:343). Moses moes vir Israel gaan sê dat sy Naam "EK IS" is. Hy is "die HERE (רדור), die God van julle vaders ..." (3:15). Vergelyk ook Jesaja 42:8; 43:11; 44:6; 45:18, 22; Jer. 32:27; Mal. 3:6. 
Die sentrale openbaring in die O.T. en die Christelike grondslag van die PU

Die vertaling van אהיה אשר אהיה het al baie probleme opgelewer (vgl.

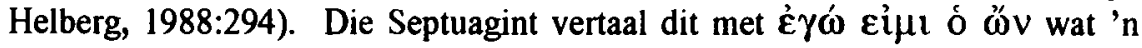
ontiese konnotasie het. Die Hebreeuse werkwoorde het egter 'n meer dinamiese karakter. Die wese van God en sy optrede moet egter nie teenoor mekaar afgespeel word nie (Childs, 1974:88). Die predikaatlose אהיה (Iste pers. Qal. imperf.) dui 'n onvoltooide of voortdurende handeling aan wat betrekking het op wat-nie-genoem-word-nie. In plaas van die predikaat volg 'n bystelling met dieselfde waarde - אשר אריח. Twee keer volg die "EK IS". Hy is volledig, absoluut, ewig, oral, onverklaarbaar. Hy is die Een, $\mathrm{Hy}$ is in sy wese altyd daar, Hy is handelend, besig, werkend, aktief, dinamies, leweskeppend, self onmeetlik (vgl. ook Calvyn, 1984:56). Hy is almagtig, vrymagtig, soewerein (vgl. Helberg, 1988:296-997; vir "soewerein" vgl. Deist, 1984:160). Moses kry wel 'n antwoord maar op so ' $n$ wyse dat hy nie die ewige geestelike wese in 'n formule kan saamvat nie. Hy kan bewus word van Jahweh se teenwoordigheid maar weet nie wat om te verwag nie; daarom krimp hy van vrees ineen (3:6).

In Eksodus 6:2[3] gee Jahweh te kenne dat Hy ook sy Naam יהוד aan Moses bekend gemaak het. (Hier word nie ingegaan op die probleem met betrekking tot die bekendheid van die naam voor Moses se tyd nie en ook nie die sogenaamde Midianiete- of Kenniete-hipotese nie - vgl. Jenni, 1971:704; Clements, 1978:63; De Groot \& Hulst, s.j.:127-139). Met die betekenis van die naam יהוה word die ondersoeker weer in die duister gedompel. (Die etimologie is onseker, die verhouding met איר word betwyfel, ens. - vgl. Zimmerli, 1987:19-20; Freedman \& O'Conner, 1986:515.) Die vorm יהוה word as 'n 3de manlike persoonsvorm in die imperfektum beskou (vgl. De Groot \& Hulst, s.j.:140). Maar is dit 'n Qal. of 'n Hi.? Lê die klem op die handelende of op die veroorsakende (kousatiewe)? Vir albei moontlikhede is daar baie argumente aangevoer (vgl. Jenni, 1971:703; Freedman \& O'Conner, 1986:516), maar per slot van sake kan in die lig van wat reeds gesê is, veronderstel word dat die handelende die veroorsakende insluit. Van belang is dat God sy Naam in 'n werkwoordsvorm geopenbaar het waarin die mens Hom (3de pers.) as die Een wat dinamies IS, moet leer ken. Hoe en wat Hy IS en wat $\mathrm{Hy}$ doen, sal die mens in die geskiedenis en in die ondersoek van die Woord en die skepping vaagweg kan vasstel. Vaagweg, want die mens sal God nooit ten volle kan ken nie, maar hy sal tog genoegsame kennis verkry om Hom te eer (vgl. Eks. 8:22; Eseg. 6:7; 7:9; 12:15), sy gemeenskap te ervaar, sy heerskappy te erken, sy liefde en verlossing te smaak en om ewig saam met Hom te lewe.

Die Ou Testament is vol van die woord en daad van Jahweh. Sy naam in al sy vorme kom 6828 keer voor (Jenni, 1971:704). (Dit is so jammer dat die naam 
F.N. Lion-Cachet

Jahweh in die vertalings alreeds vanaf die Joodse vertaling, die Septuagint, verlore gegaan het. Dit is ' $n$ gebrek dat die naam Jahweh nie eers in die NAV uitgeken kan word nie.) Von Rad (1965:362-363) beweer dat "(i)f it were to be said, however, that Jahweh is the focal-point of the Old Testament, this again would not be sufficient; for, we have seen, Israel was hardly ever at rest in her relationship with God ... But the situation in the Old Testament does correspond to the view variously expressed in the New that the true goal of God's relationship with Israel is the coming of Jesus Christ". Hier word op indirekte wyse die sentrale betekenis van die kenne van Jahweh erken, maar dan, Israel het rus gesoek in die uitwendige selfgeïdealiseerde godsdiens, en tereg, die ware rus kan alleen in Christus gevind word.

\subsection{Jahweh, die God van die vaders (in 'n verbonds- verhouding)}

$\mathrm{Na}$ God se selfopenbaring aan Moses as "EK IS" (Eks. 3:14) gee Hy in die daaropvolgende opdrag 'n eerste invulling van wie Hy is. Hy is Jahweh, die God van hulle vaders, "die God van Abraham, die God van Isak en die God van Jakob (3:15; vgl. ook 3:6, 16; 6:2-3 [3-4]). Die term wלהימ wat in al sy vorme 2570 keer in die Ou Testament voorkom, is in die Ou Ooste meesal as 'n soortnaam gebruik (vgl. Quell, 1965:81; De Groot \& Hulst, s.j.:85). Die stam $\zeta$ (ר)א of sinonieme is in die Semitiese taalwêreid gebruik om 'n bomenslike wese of krag wat onder andere (al)magtigheid, verhewenheid, heerlikheid, sterkte, goedheid, meegevoel, geestelikheid, tegemoetkomendheid en geregtigheid besit, aan te dui (vgl. Ringgren, 1974:267-272). In die Ou Testament word geen omskrywing van wie God is, gegee nie (Clements, 1978:52) en tog is die God van Israel sentraal in die Ou Testament (vgl. Freedman \& O'Conner, 1986:517).

Jahweh sê dat Hy die God van Abraham, Isak en Jakob is $(3: 6,16)$. In Eksodus 6:2 [3] gee God meer te kenne van sy bekendstelling in die patriargale tyd: "Ek is die HERE en het aan Abraham, aan Isak en aan Jakob verskyn as God die Almagtige". Die lyn kan nou terug getrek word na die selfbekendstelling aan Abraham in Genesis 17:1: "Ek is God die Almagtige" (vgl. ook Gen. 15:1). $\mathrm{Hy}$ is die God van die voorvaders, die God van besondere enkelinge met wie Hy 'n verbond gesluit het (vgl. Eks. 2:24; 6:3 [4] ook Gen. 15:18), die God van Abraham se nageslag (Gen. 17:7; vgl. ook Jer. 24:7), maar ook van die geslagte wat in Abraham se seën sal deel (Gen. 12:3).

By die verbondsluiting met Israel by Sinai (Eks. 19, 20, 24) is dit weer opmerklik dat die enkeling aangespreek word: "Ek is die HERE jou God wat jou uit Egipteland, uit die slawehuis, uitgelei het" (20:2). 
Is Hy Jahweh, die God van die verbond met Israel wat net vir die gelowiges in Israel van betekenis is? Is Hy net die God van Israel? (vgl. Quell, 1965:82; Ringgren, 1974:276; Clements, 1978:56). Hierdie afleiding moet verwerp word. Hy is die God van die ganse skepping (Gen. 2:4 e.v.; Jes. 45:18), maar ook van alle vlees (Jer. 32:27). Hy is God van alle nasies (Ps. 22:28), van alle mense (Jes. 56:3) maar Hy bewys sy genade en liefde in besonder aan dié wat Hy verkies het. Hy het in die Ou-Testamentiese bedeling veral vir Israel gekies maar $\mathrm{Hy}$ het ander mense nie verbygegaan nie. Israel het in die Ou Testament 'n meer religieuse betekenis gehad (vgl. Helberg, 1993:58). Die klem val meer op Israel as die volk (kerk) van God. Hy is daarom ook die jaloerse God wat geen ander god of afgodsbeeld naas Hom duld nie (Eks. 20:3-5; Deut. 6:4). Hy eis van sy volk eerlike en opregte liefde in hulle godsdiens.

\subsection{Jahweh, die God wat verlos}

In die roepingsgeskiedenis (Eks. 3:1-4:17) het Jahweh Hom bekendgestel as die God wat Israel uit Egipte gaan verlos (3:7-10, 16-22). In die uittoggebeure sou Israel Jahweh op 'n besondere wyse leer ken. Die verlossing uit Egipte is dié vrymagtige daad van Jahweh wat die belangrikste gebeure in die geloofservaring van Israel sou word (vgl. Zimmerli, 1978:21-25; vgl. ook Eks. 20:1; 29:29; Deut. 5:6; 32:9-10; Ps. 29:11; Jes. 43:3; Hos. 13:4; Eseg. 16:3-14).

\subsection{Jahweh, die God wat in 'n persoonlike gemeenskap met die mens staan}

Moses se eerste beswaar teen sy roepingsvervulling was die besef van eie nietigheid. "Wie is ek ... ?" (Eks. 3:11). Hierop het Jahweh gesê: "EK IS inderdaad (כ) by jou ..." Hy is die God van persoonlike gemeenskap (vgl. Helberg, 1980:4). Die feit is alreeds in die aartsvadergeskiedenis genoem (Gen. $26: 24 ; 28: 15$ ). Hy sal by sy knegte wees (Jer. 1:8,9). Jahweh openbaar hom ook as die God wat by Israel is (Jes.41:10; 43:5; Jer. 30:11).

\subsection{Jahweh, die Heilige God}

As Moses by Horeb die vuurvlam uit die doringbos sien, wil hy die doringbos nader. Alle klem val op die vuurvlam en dit dui op die teofanie van 'n verterende en onveranderlike wese (Fensham, 1970:23-24). Jahweh waarsku hom om nie nader te kom nie, want die plek waarop hy staan, is heilige grond. God neem alle inisiatief om aan Moses te verskyn en sy besondere teenwoordigheid maak die grond heilig, want Jahweh is heilig (vgl. Helberg, 1988:287 288). In die Pentateug stel Jahweh Hom duideliker as die heilige bekend (vgl. Lev. 11:44; 20:7 en Jes. 43:3,15; 48:17; Eseg. 39:7; Joël 3:17 [4:17]). 
F.N. Lion-Cachet

\subsection{Jahweh, die Skepper}

In Jahweh se dialoog met Moses gee Hy ook te kenne dat Hy die een is wat die mond gemaak het (Eks. 4:10). Hy is die Skepper. In die profesie van Jesaja sê Jahweh met soveel woorde dat Hy die Skepper is (vgl. Jes. 43:15; 44:24; 45:18). Dat die kosmos die skepping van Jahweh is, is vir die akademiese arbeid van die Universiteit van groot betekenis. Dit is juis die skeppingsrealiteit wat die voorwerp van wetenskaplike ondersoek is, en die kennis van die skepping bring die ondersoeker op sy knieë voor Jahweh.

\subsection{Jahweh is alleen God, die Wetgewer en Koning en ...}

In Eksodus 3:1-4:17 openbaar God Hom as Jahweh, "HY WAT IS" en Hy begin reeds invul Wie hy is. Om meer van Jahweh te leer ken, is dit egter nodig om die selfbekendstellings in die ander dele van die Ou Testament na te gaan. Hy is die Wetgewer (vgl. die Dekaloog in Eks. 20:2-17; Deut. 5:6-21, 33); die Koning (vgl. Jes. 43:15; 44:6), die Vader (Jer. 31:9). Tog is dit 'n onmoontlike taak om 'n volledige definisie van Jahweh te gee. Hy is Enig. In Deuteronomium 6:4 val die klem nie net op die verborgenheid en sonderlingheid van sy wese nie maar ook op die absolute enigheid van sy bestaan. Daar is naas Hom geen ander nie (vgl. 32:39; Jes. 43:10; 44:6; 45:5), daar is geen wese met wie Hy vergelyk kan word nie (Jes. 40:18).

\section{Nuwe-Testamentiese gegewens}

Alhoewel die klem in hierdie artikel op die Ou-Testamentiese openbaring val, is die paar Nuwe-Testamentiese verwysings volledigheidshalwe dringend noodsaaklik. Jahweh se selfopenbaring in Christus vervul die verwagting wat in die $\mathrm{Ou}$ Testament geskep is.

\subsection{Christus is die Seun van God}

In die Nuwe Testament word die geboorte van Christus deur engele aangekondig (Luk. 1:26, 28; 2:10-12; Matt. 1:20). Die eerste selfopenbaring van God geskied by die doop van Christus. Die stem uit die hemel sê: "Dit is my geliefde Seun in wie Ek 'n welbehae het" (Matt. 3:16-17; vgl. Mark. 1:1011; Luk. 3:21-22) en later op die berg van verheerliking: "Dit is my geliefde Seun in wie Ek 'n welbehae het; luister na Hom" (Matt. 17:5; vgl. Mark. 9:7; Luk. 9:35). Hier is sprake van 'n stem, God se stem (Grosheide, 1954:51, 268). God sê hier niks van Homself nie. In Openbaring 1:8 is die goddelike getuienis sterker: "Ek is die Alfa en die Oméga, die begin en die einde, sê die Here, wat is en wat was en wat kom, die Almagtige" (vgl. ook Op. 4:8 en 21:6). Die woord herinner aan die selfopenbaring in Eksodus 3:14. 
Die woorde by die doop en op die berg maak ook die verhouding tussen God en Christus bekend. Hy is die Seun. Jesus getuig later dat Hy en die Vader een is (Joh. 14:10-11) en aanvaar die belydenis van Petrus dat Hy die Christus, die Seun van God is (Matt. 16:15-16, vgl. ook Luk. 22:70; vgl. ook Grosheide, 1954:254). Hy is die ewige (God) want "voordat Abraham was, is Ek" (Joh. 8:58). Stauffer (1964:353) merk op dat "( $t$ )he egô of Christ is the subject of the history of God, and his history will be nothing but a powerful self-proclamation of Christ". In Openbaring sê Hy van Homself dieselfde as wat God van Homself gesê het: "Ek is die Alfa en die Oméga, die eerste en die laaste ..." (vgl. 1:8 en 11, 21:6 en 22:13) en in 1:18 voeg Hy by "en die lewende; en Ek was dood en kyk, Ek leef tot in ewigheid". Bogenoemde impliseer 'n absolute eenheid (vgl. Stauffer, 1964:351).

Jesus getuig met goddelike gesag van Homself (Joh. 8:18). Hy erken dat Hy die Christus is (Matt. 16:15-17; Joh. 4:26; vgl. Op. 22:16 waar Hy sê: "Ek is Jesus ... Ek is die wortel en die geslag van Dawid, die blink môrester").

Christus maak Homself dus in die Nuwe Testament bekend as Christus, die Messias, die Seun van God wat by die mense is (vgl. Matt. 16:15-17; 14:61-12; Luk. 22:70; Joh. 14:10-11).

\subsection{Christus is "EK IS" (}

In die Johannes-evangelie is die oorheersende trek van die Christus-redes die

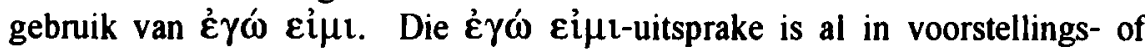
identifikasie- of herkenningsformules ingedeel, maar kom primêr daarop neer dat Hy sê: "Ek, alleen Ek" (vgl. Grosheide, 1950:301). "Ek is ... Ek", "Ek is die ware Een", en ten slotte rus dit in "EK IS WAT EK IS" van Eksodus 3:14 (vgl. Stauffer, 1964:352; Groenewald, 1980:110).

Net soos in die Ou Testament kan die predikaatlose EK IS ingevul word. Christus is die Verlosser: Hy is die brood van die lewe (Joh. 6:35, 41-51), die deur (Joh. 10:7-9), die opstanding (Joh. 11:25), die weg, die waarheid en die lewe (Joh. 14:6), die ware wynstok (Joh. 15:1), en die sentrale uitspraak is opgeteken in Johannes 8:23-28: "... as julle nie glo dat dit Ek is nie, sal julle in julle sondes sterwe ..." (vgl. Stauffer, 1964:353).

In aansluiting by die prediking van die koninkryk wat naby gekom het, erken Hy dat Hy die Koning is (Joh. 18:37) aan wie alle mag in die hemel en aarde toekom (Matt. 28:18). Hy het die mag om mense se siektes te genees, dooies op te wek, maar ook om die natuur te beheer (Matt. 14:27; Mark. 6:50). Hy is persoonlik by sy volgelinge: "Ek is die goeie herder" (Joh. 10:11), "Ek is met julle al die dae tot aan die voleinding van die wêreld", "Ek is sagmoedig en nederig van hart" (Matt. 11:29). Hy is die lig van die wêreld (Joh. 8:12). 
F.N. Lion-Cachet

\section{Samevatting}

* Uit bogenoemde blyk dat die selfbekendstelling of selfidentifikasie van God in die Ou Testament "EK IS WAT EK IS" is - 'n selfbekendstelling wat as die sentrale kennis of openbaring aan die volk deurgegee moet word. Die volk moet Hom egter Jahweh (HY IS) noem. In hierdie openbaring is bekendmaking én verberging. Sy volk sal alle kennis ontvang wat hulle moet ontvang maar sal nie absoluut alles in 'n neutedop kan saamvat nie. Jahweh, die God van sy volk is meer as wat enige boek of ondersoek ooit van Hom kan sê.

* Die Ou Testament is eerstens die openbaringsboek van "Jahweh", die God van Israel (sy volk, sy "kerk") maar ook van die gelowiges uit alle volke. Tog word daar op die volle realiteit van Jahweh, die God van sy volk gewag. Israel sondig, word in ballingskap verwerp. Hoe sal die herstel wees? Hoe sal die ander volke bykom?

In die Nuwe Testament is daar 'n direkte aansluiting by die Ou Testament. Jesus is die Christus, die Messias, die Seun van God en Hy openbaar Homself as die een wat is en wat was en wat kom. Hy is die eerste en die laaste. Hierdie bekendstelling het dieselfde omvang as die kennis van Jahweh deur wat geopenbaar en wat nog verberg bly, maar wat bykom, is sy naam Jesus. Hy sal Israel verlos en gelowiges by die ou Israel (die kerk) byvoeg.

* Die Nuwe Testament is die openbaring van God in Christus. Wie Christus ken, ken die Vader, ken Jahweh wat Hom in die Ou Testament geopenbaar het. Dit is weer opmerklik dat geen absolute rasionele omskrywing van God in Christus moontlik is nie (die wonder van sy geboorte, opstanding en hemelvaart bly onbegryplik) en dat die verhouding tussen God in Christus en die mens so ryk gevarieerd is dat dit nie eensydig in 'n enkele begrip (die koninkryk, die verbond, die wetsidee, die regsbeginsel, die verlossing, die antropologies-sedelike lewenswyse, ens.) saamgevat kan word nie.

* Volgens die Ou en Nuwe Testament gaan dit in die skepping en die menselewe om die eer van die HERE God wat Hom in die skepping en verlossing van die ganse kosmos in Christus genoegsaam geopenbaar het. Alleen in die persoon van Christus is die volle bevryding van enige mensgeoriënteerde benadering in enige wêreld- of mensbeskouing, naïef of akademies moontlik.

* Die Universiteit kan dus sy grondslag in die openbaring van God in die skepping en op duideliker wyse in die Skrif (Ou en Nuwe Testament) vind en sonder enige teenspraak stel dat sy grondslag Christelik is. Jahweh, die enigste God, die God van die skepping en herskepping, die God van sy 
volk (die uitverkorenes uit Israel en alle ander nasies) kan alleen in Christus geken word. Christus wat ten volle God is, is die enigste deur om tot die HERE te nader en sy skepping so volledig moontlik te leer ken. Hierdie besondere begronding bied die geleentheid aan die Universiteit om die skeppingsrealiteite (die siellose kosmos en al die geestelike wesens) as navorsingsobjek te neem, sy studente te onderrig en Suid-Afrika en sy mense te dien. Dit is juis hierdie Christelike perspektief wat die Universiteit in sy akademiese arbeid van alle -ismes bevry en vemuwend die weg na die toekoms (ook die ewige toekoms) aanwys.

\section{Bibliografie}

BAVINCK, H. 1918. Gereformeerde Dogmatiek. Deel 1. Kampen : Kok.

CALVYN, J. 1984. Verklaring van de Bijbel. Harmonie van de laatste vier boeken van Moses I. (Vert. Van den Heuvel.) Kampen : De Groot.

CHILDS, B.S. 1974. Exodus (OTL). London : SCM.

CHILDS, B.S. 1989. Old Testament Theology in a Canononical Context. Philadelphia : Fortress.

CLEMENTS, R.E. 1978. Old Testament Theology. A Fresh Approach. London : Marshall, Morgan \& Scott.

DEIST, Ferdinand. 1984. A Concise Dictionary of Theological Terms. Pretoria : Van Schaik.

DE GROOT, J. \& HULST, A.R. s.j. Macht en wil. Nijkerk : Callenbach.

EICHRODT, W. (1959) 1961. Theology of the Old Testament, I. (Tr. Baker, J.A.) London : SCM.

FENSHAM, F.C. 1970. Exodus (POT). Nijkerk : Callenbach.

FREEDMAN, D.N. \& O'CONNER, M.P. 1986. JHWH. (In Botterweck, G.J. \& Ringgren, H., red. Tr. Willis, J.T. Theological Dictionary of the Old Testament V. Grand Rapids : Eerdmans. p. 500-521.)

GROENEWALD, E.P. 1980. Die evangelie van Johannes. Kaapstad : N.G. Kerkboekhandel.

GROSHEIDE, F.W. 1950. Het heilig evangelie volgens Johannes I. Amsterdanı : Bottenburg.

GROSHEIDE, F.W. 1954. Het heilig evangelie volgens Mattheus. Kampen : Kok.

GUNTHER, K. 'anî ich. 1971. (In Jenni, E., red. Theologisches Handwörterbuch zum Alten Testament, Vol. I. München : Kaiser Verlag. p. 215220.)

HASEL, G.F. 1972. Old Testament Theology: Basic Issues in the Current Debate. Grand Rapids : Eerdmans.

HAYES, J.H. \& PRUSSNER, F.C. 1985. Old Testament Theology. Its History and Development. London : SCM. 
HELBERG, J.L. 1980. Die Here regeer. Openbaringslyn deur die Ou Testament. Pretoria : N.G. Kerkboekhandel.

HELBERG, J.L. 1988. Die selfbekendstelling van God in Eksodus 3 en die betekenis daarvan vir vandag. Koers, 53(3):280-304.

HELBERG, J.L. 1993. Openbaringsgeskiedenis van die Ou Testament. Inleiding. (D 243/93) Potchefstroom : DSP.

JENNI, E. 1971. יהרה. (In Jenni, E., red. Theologisches Handwörterbuch zum Alten Testament, Vol. I. München : Kaiser Verlag. p. 701-707.)

KAISER, Walter C. (Jr.) 1991. Toward an Old Testament Theology. Grand Rapids : Zondervan.

LION-CACHET, F.N. 1995. Die spektrum en dinamiek van die Gereformeerde teologie. In die Skriflig, 29(1 \& 2):29-46.

NOTH, M. 1962. Exodus (OTL). London : SCM.

QUELL, G. 1965. El and Elohim in the OT. (In Kittel, G., ed. Theological Dictionary of the New Testament III. Grand Rapids : Eerdmans . p. 7989.)

RINGGREN, H. 1974. אלדימ. (In Botterweck, G.J. \& Ringgren, H., ed. Tr. Willis, J.T. Theological Dictionary of the Old Testament. Grand Rapids : Eerdmans. p. 267-284.)

SCHMIDT, W.H. 1983. The Faith of the Old Testament. (Tr. Sturdy, John). Oxford : Blackwell.

SMEND, R. 970. Die Mitte des Alten Testaments. Zürich : EVZ-Verlag.

STAUFFER, E. 1964. غ́ $\gamma \hat{\omega}$. (In Kittel, G., ed. Theological Dictionary of the New Testament Il. Tr. Bromiley, G.W. Grand Rapids : Eerdmans. p. 343-362.)

STEK, J.H. 1994. "Covenant" Overload in Reformed Theology. Calvin Theological Journal, 29(1):12-41.

VON RAD, G. (1960) 1965. Old Testament Theology. Vol. II. (Tr. Stalker, D.M.G.) Edinbugh : Oliver and Boyd.

WRIGHT, G.E. 1951. The Faith of Israel. (In Buttrick, G.A. ed. The Interpreter's Bible. New York : Abingdon Press. p. 349-350.)

ZIMMERLI, W. 1978. Old Testament Theology in Outline. (Tr. Green, D.E.) Edinburg : Clark. 
